\title{
IDENTIFIKASI BIAYA PENGENDALIAN HAMA DAN PENYAKIT PADA BEBERAPA TANAMAN HORTIKULTURA DI DESA PALELON KECAMATAN MODOINDING
}

\author{
IDENTIFICATION OF PEST AND DISEASE CONTROL COSTS ON SOME \\ HORTICULTURAL PLANT IN PALELON VILLAGE, MODOINDING DISTRICT
}

\author{
$\underline{\text { Merifka Rahel Ratu }}^{(1)}$, Olly Esry H. Laoh ${ }^{(2)}$, Paulus A.Pangemanan ${ }^{(2)}$ \\ 1) Mahasiswa Program Studi Agribisnis, Fakultas Pertanian, Universitas Sam Ratulangi, Manado \\ 2) Dosen Program Studi Agribisnis, Fakultas Pertanian, Universitas Sam Ratulangi, Manado \\ *Penulis untuk korespondensi: merifkaratu@gmail.com
}

\begin{tabular}{llr}
\hline Naskah diterima melalui Website Jurnal Ilmiah agrisosioekonomi@unsrat.ac.id & $:$ & Rabu, 14 April 2021 \\
Disetujui diterbitkan & $:$ & Jumat, 28 Mei 2021 \\
\hline
\end{tabular}

\begin{abstract}
The purpose of this study was to determine the cost of controlling pests and diseases in horticultural crops (potatoes, onions, cabbage) in Palelon Village, Modoinding District. Pest and disease control activities in this study include activities ranging from tillage and weeding, nursery, control or protection, and maintenance or care. This study started from December 2019 to February 2020. The data used in this study were primary and secondary data. The method of data collection is purposive sampling. The data analysis method in this study was analyzed descriptively which was presented to describe or describe the data collected using tables. Based on the results of the study, it can be concluded that the highest control costs incurred by farmers are maintenance costs, then weeding/land processing, and control and seeding.
\end{abstract}

Keywords : horticulture; cost; pests and diseases

Tujuan dalam penelitian ini adalah untuk mengetahui biaya pengendalian hama dan penyakit pada tanaman hortikultura (kentang, bawang, kubis) di Desa Palelon Kecamatan Modoinding. Kegiatan pengendalian hama dan penyakit dalam penelitian ini meliputi kegiatankegiatan mulai dari pengolahan tanah dan penyiangan, pembibitan, pengendalian atau perlindungan, dan pemeliharaan atau perawatan. Penelitian ini dimulai dari bulan Desember 2019 sampai bulan Februari 2020. Data yang digunakan dalam penelitian ini adalah data primer dan sekunder. Metode pengambilan data secara purposive sampling yaitu secara sengaja. Metode analisis data dalam penelitian ini dianalisis secara deskriptif yang disajikan untuk mendeskripsikan atau menggambarkan data yang terkumpul dengan menggunakan tabel. Berdasarkan hasil penelitian dapat disimpulkan bahwa biaya pengendalian tertinggi yang dikeluarkan petani yaitu biaya pemeliharaan, kemudian penyiangan/pengolahan lahan, dan pengendalian serta pembibitan.

Kata kunci : hortikultura; biaya; hama dan penyakit 


\section{PENDAHULUAN}

\section{Latar Belakang}

Indonesia hingga saat ini masih tergolong negara yang sedang berkembang dengan tingkat pertumbuhan penduduk yang tinggi. Selain itu juga Indonesia merupakan negara agraris dimana sebagian besar penduduknya berada di pedesaan dengan mata pencaharian di sektor pertanian. Dalam rangka pembangunan perekonomian di Indonesia, maka semua potensi digunakan dan dimanfaatkan untuk lebih meningkatkan pembangunan itu sendiri, khususnya di sektor pertanian. Pembangunan di sektor pertanian dapat memperluas lapangan pekerjaan, meningkatkan pendapatan petani, peternak dan pekebun serta mendorong pemerataan pembangunan daerah dengan tetap memperhatikan kelestarian sumberdaya alamnya (Daniel, 2002).

Tanaman hortikultura sangat berperan dalam kehidupan manusia, karena merupakan sumber gizi yang menjadi pelengkap makanan pokok yang berpengaruh terhadap kondisi kesehatan manusia. Selain itu, tanaman hortikultura merupakan sumber berbagai vitamin dan mineral yang sangat dibutuhkan oleh tubuh manusia. Komoditas hortikultura yang diutamakan adalah komoditas yang bernilai ekonomi tinggi, mempunyai peluang pasar besar dan mempunyai potensi produksi tinggi serta mempunyai peluang pengembangan teknologi. Adapun upaya yang dilaksanakan untuk mendorong tumbuh dan berkembangnya hortikultura unggulan, yaitu meliputi penumbuhan sentra agribisnis hortikultura dan pemantapan sentra hortikultura yang sudah ada (Soleh, 1999).

Pada umumnya petani menggunakan faktor produksi secara berlebihan dengan harapan akan memperoleh hasil yang maksimal. Padahal penggunaan faktor produksi yang berlebihan akan meningkatkan biaya produksi yang pada akhirnya akan mengurang pendapatan usaha tani jika tambahan biaya yang dikeluarkan lebih tinggi daripada tambahan penerimaan karena didalam pertanian dikenal dengan hukum Kenaikan Hasil yang Semakin Berkurang (The Law of Deminishing Return). Kondisi tersebut merupakan salah satu tindakan yang dilakukan petani saat ini dalam pengembangan hortikultura pada khususnya, karena dalam pengusahaannya dituntut untuk efisien dan mampu meningkatkan hasil. Oleh karena itu dalam pengembangan hortikultura tidak lagi hanya memperhatikan aspek produksi, tetapi lebih menitik beratkan pada pengembangan komoditi yang berorientasi pasar/agribisnis (Sunu dan Wartoyo, 2006).

Modoinding adalah salah satu kecamatan di Kabupaten Minahasa Selatan. Desa Palelon adalah salah satu dari delapan desa yang ada di Kecamatan Modoinding. Letak geografis desa Palelon berada pada posisi yang strategis karena berada di lintas darat yang menghubungkan dua wilayah yaitu : wilayah kecamatan Maesaan dan Kabupaten Bolaang Mongondow. Desa Palelon memilki luas 524,5 ha, dengan topografi wilayah berupa dataran tinggi. Umunya penduduk desa Palelon berprofesi sebagai petani dalam berbagai jenis-jenis tanaman hortikultura. Dalam bertani penggunaan pestisida memang telah memberikan kontribusi besar bagi peningkatan produksi tanaman hortikultura. Penggunaan pestisida telah dianggap sebagai metode yang paling efektif dalam pengendalian hama dan penyakit. Oleh karena itu sejak dipergunakannya secara luas pestisida organik sintetik, maka pada masyarakat timbul peradangan atau pendapat bahwa tanpa pestisida tidak mungkin diperoleh produksi pertanian yang tinggi atau dengan kata lain pestisida merupakan jaminan atau asuransi bagi tercapainya sasaran produksi.

\section{Konsep Usahatani}

Usahatani adalah ilmu yang mempelajari tentang cara petani mengelola input atau faktorfaktor produksi (tanah, tenaga kerja, teknologi, pupuk, benih, dan pestisida) dengan efektif, efisien, dan kontinyu untuk menghasilkan produksi yang tinggi sehingga pendapatan usahataninya meningkat (Rahim dan Hastuti, 2007).

Menurut Soekartawi (2002), ilmu usahatani biasa diartikan sebagai ilmu yang mempelajari bagaimana seseorang mengalokasikan sumberdaya yang ada secara efektif dan efisien untuk tujuan memperoleh keuntungan yang tinggi pada waktu tertentu. Dikatakan efektif bila petani dapat mengalokasikan sumberdaya yang mereka miliki (yang dikuasai) sebaik- baiknya, dan dikatakan efisien bila pemanfaatan sumberdaya tersebut menghasilkan keluaran (output). 
Sehingga dapat disimpulkan bahwa Ilmu usahatani adalah ilmu terapan yang membahas atau mempelajari bagaimana menggunakan sumberdaya secara efisien dan efektif pada suatu usaha pertanian agar diperoleh hasil maksimal. Sumberdaya itu adalah lahan, tenaga kerja, modal dan manajemen.

\section{Konsep Hortikultura}

Kata hortikultura (horticulture) berasal dari bahasa latin, yakni hortus yang berarti kebun dan colere yang berarti menumbuhkan (terutama sekali mikro organisme) pada medium buatan. Secara harfiah, hortikultura berarti ilmu yang mempelajari pembudidayaan tanaman kebun. Akan tetapi pada umumnya para pakar mendefinisikan hortikultura sebagai ilmu yang mempelajari budidaya tanaman sayuran, buahbuahan, bunga-bungaan, atau tanaman hias. Orang yang ahli mengenai hortikultura (pakar hortikultura) dikenal sebagai seorang horticulturist (Zulkarnain, 2014).

Hortikultura adalah budidaya pertanian yang dicirikan oleh penggunaan tenaga kerja dan prasarana serta sarana produksi secara intensif. Konsekuensi dari kegiatan usahatani hortikultura, tanaman yang dibudidayakan dipilih yang berdaya menghasilkan pendapatan tinggi (alasan ekonomi) atau yang berdaya menghasilkan kepuasan pribadi besar (alasan hobi), dan terbagi dalam satuan usaha terbatas (Notohadinegoro dan Johara, 2005).

Tanaman hortikultura merupakan salah satu tanaman yang menunjang pemenuhan gizi mayarakat sebagai sumber vitamin, mineral, protein, dan karbohidrat. Produksi hortikultura yaitu sayuran dan buah-buahan menyumbang pertumbuhan sektor pertanian nasional masingmasing sebanyak 3,1 juta ton dan 2,6 juta ton (Sugiarti, 2003).

\section{Konsep Biaya}

Biaya adalah semua pengorbanan yang perlu dilakukan untuk suatu proses produksi, yang dinyatakan dengan satuan uang menurut harga pasar yang berlaku, baik yang sudah terjadi maupun yang akan terjadi. Carter (2009), mendifinsikan "biaya sebagai suatu nilai tukar, pengeluaran, atau pengorbanan yang dilakukan untuk menjamin perolehan manfaat". $\begin{array}{ccc}\text { Menurut } & \text { Siregar } & (2014) \text { biaya adalah } \\ \text { pengorbanan sumber ekonomi untuk }\end{array}$ memperoleh barang atau jasa yang diharapkan memberi manfaat sekarang atau masa yang akandatang. Menurut Purwanti dan Prawironegoro (2013) biaya adalah kas dan setara kas yang dikorbankan untuk memproduksi atau memperoleh barang atau jasa yang diharapkan akan memperoleh manfaat atau keuntungan dimasa mendatang.

Biaya merupakan pengorbanan atau pengeluaran yang dilakukan oleh suatu perusahaan atau perorangan yang bertujuan untuk memperoleh manfaat lebih dari aktivitas yang dilakukan tersebut Biaya merupakan unsure utama secara fisik yang harus dikorbankan demi kepentingan dan kelancaran perusahaan dalam rangka menghasilkan laba yang merupakan tujuan utama perusahaan. (Rahartjaputra, 2009).

\section{Pengendalian Hama dan Penyakit}

Smith dalam Untung

mendefinisikan Pengendlian Hama Terpadu atau PHT sebagai pengendalian hama yang menggunakan semua teknik dan metode yang sesuai dalam cara-cara yang seharmonis mungkin dalam mempertahankan populasi hama di bawah tingkat yang menyebabkan kerusakan ekonomi di dalam lingkungan dari dinamika populasi spesies hama yang bersangkutan. Pengendalian hama terpadu tidak hanya terbatas sebagai teknologi pengendalian hama yang berusaha memadukan berbagai teknik pengendalian termasuk pengendalian secara kimiawi yang merupakan alternatif terakhir, tetapi mempunyai makna yang lebih mendasar lagi. PHT adalah suatu konsep ekologi, falsafah, cara berpikir, cara pendekatan berdasar pada konsep, ekonomi dan budaya yang menitip beratkan pada potensi alami seperti musuh alami, cuaca serta menempatkan manusia sebagai pengambil keputusan dalam pengeloalaan usahataninya.

Pengendalian Hama Terpadu adalah cara pengendalian yang digunakan untuk mencapai stablitas produksi, dengan kerugian seminimal mungkin kesehatan manusia dan lingkungan. Timbulnya PHT merupakan koreksi terhadap sistem pengendalian hama secara konvensional yang selalu mengutamakan penggunaan 
pestisida untuk memberantas hama tanaman. Penggunaan pestisida secara berlebihan untuk membunuh hama, seringkali juga membunuh organisme selain hama dalam suatu ekosistem. Apabila yang terbunuh justru organisme yang menguntungkan bagi pengendalian hama maka pada suatu saat akan terjadi ledakan hama sekunder yang besar sehingga penggunaan pestisida kurang efektif lagi.

Pengendalian Hama Terpadu adalah teknologi pengendalian hama yang didasarkan prinsip ekologis dengan menggunakan berbagai teknik pengendalian yang sesuai antara satu sama lain sehingga populasi hama dapat dipertahankan di bawah jumlah yang secara ekonomik tidak merugikan serta mempertahankan kesehatan lingkungan dan menguntungkan bagi pihak petani.

\section{Karakteristik Tanaman Hortikultura}

\section{Kentang}

Kentang (Solanum tuberosum L.) merupakan tanaman sayuran semusim, berumur pendek kurang lebih hanya 90-180 hari dan berbentuk perdu atau semak. Bervariasi sesuai varietasnya (Samadi, 1997).

Kentang merupakan tanaman umbiumbian dan tergolong tanaman berumur pendek. Tumbuhnya bersifat menyemak dan menjalar dan memiliki batang berbentuk segi empat. Batang dan daunnya berwarna hijau kemerahan atau berwarna ungu. Umbinya berawal dari cabang samping yang masuk ke dalam tanah, yang berfungsi sebagai tempat menyimpan karbohidrat sehingga bentuknya membengkak. Umbi ini dapat mengeluarkan tunas dan nantinya akan membentuk cabang yang baru (Aini, 2012).

Menurut Gunarto, (2003) kentang (Solanum tuberosum L.) merupakan tanaman pangan bernilai ekonomi tinnggi yang dapat mendatangkan keuntungan (cash crop) bagi pengusaha industri makanan olahan, pedagang dan petani yang membudidayakannya.

\section{Kubis}

Kubis atau kol dengan nama latin (Brassica Oleracea Var Capitata) pada mulanya merupakan tumbuhan liar di daerah subtropik. Tanaman ini berasal dari daerah Eropa yang ditemukan pertama di Cyprus, Italia dan
Mediteranian. Tanaman kubis termasuk dalam golongan tanaman sayuran semusim atau umur pendek. Tanaman kubis hanya dapat berproduksi satu kali setelah itu akan mati. Pemanenan kubis dilakukan pada saat umur kubis mencapai 60 70 hari setelah tanam (Cahyono, 2001).

Kubis dalam pertumbuhannya dapat membentuk bulatan seperti kepala atau telur. Bentuk kepala atau telur ini juga lazim disebut krop. Secara klinis, kubis banyak mengandung berbagai vitamin, mineral, karbohidrat, dan protein. Semua unsur tersebut sangat dibutuhkan tubuh manusia. Sayuran kubis dapat mensuplai kurang lebih $25 \%$ vitamin C, lebih dari $30 \%$ vitamin A, 4 - 5\% vitamin B, 5 - $6 \%$ kapur dan besi dari kebutuhan tubuh manusia.

Di Indonesia kubis termasuk tanaman annual, sedangkan di daerah sub-tropis termasuk tanaman biennial. Tergolong biennial karena pertumbuhan awalnya secara vegetatif, selanjutnya bila musim dingin tiba pertumbuhannya masuk ke masa generatif. Pembentukan bunga tergantung dari temperatur, bukan panjangnya hari. Kubis akan tumbuh baik bila ditanam di daerah berhawa dingin seperti dieng dan Pegalengan. Temperatur optimum yang dikehendaki antara 15-200C. Sedangkan kelembaban yang baik pada kisaran antara 60 $90 \%$. kalau temperatur melebihi $25 \%$, pertumbuhan akan terhambat (Pracaya, 2001).

\section{Bawang}

Bawang daun (Allium fistulosum L.) termasuk jenis tanaman sayuran daun semusim (berumur pendek). Tanaman ini berbentuk rumput atau rumpun dengan tinggi tanaman mencapai $60 \mathrm{~cm}$ atau lebih, tergantung pada varietasnya. Bawang daun selalu menumbuhkan anakan- anakan baru sehingga membentuk rumpun.

Bawang daun termasuk tanaman setahun atau semusim yang berbentuk rumput. Sistem perakarannya termasuk akar serabut yang terpencar kesemua arah pada kedalaman antar $15-30 \mathrm{~cm}$. Bagian batang semu yang tertimbun tanah umumnya berwarna keputih-putihan. Bentuk dari bawang daun yaitu bulat panjang yang didalamnya berlubang seperti pipa, kadang-kadang dapat membentuk umbi ukuran kecil. Warna daun pada umumnya hijau muda sampai hijau tua (Hidayat, 2000). 
Bunga secara keseluruhan berbentuk payung majemuk atau payung berganda (umbrella composite) dan berwarna putih. Buah bawang daun berbentuk bulat yang terbagi atas tiga ruang, berukuran kecil serta berwarna hijau muda. Biji bawang daun yang masih muda berwarna putih dan setelah tua berwarna hitam, berukuran sangat kecil, berbentuk bulat agak pipih dan berkeping satu (Sitanggang, 2008).

Bawang daun mempunyai daya adaptasi yang cukup luas terhadap lingkungan tumbuhnya. Daerah yang paling ideal untuk pengembangan bawang daun adalah dataran tinggi antara 900-1700 mdpl. Dalam budidayanya, tanaman bawang daun memerlukan tanah yang subur, gembur, banyak mengandung bahan organik, aerasi tanah yang baik dengan $\mathrm{pH}$ berkisar antara 6,5-7,5 netral (Qibtiah dan Astuti, 2016).

\section{Rumusan Masalah}

Dari latar belakang yang sudah diuraikan, maka yang menjadi permasalahan adalah berapa besar biaya pengendalian hama dan penyakit pada tanaman hortikulura (kentang, kubis, bawang)?

\section{Tujuan Penelitian}

Tujuan penelitian ini yaitu untuk mengetahui biaya pengendalian hama dan penyakit pada beberapa tanaman hortikultura (kentang, kubis, bawang).

\section{Manfaat Penelitian}

Manfaat yang diharapkan dari hasil penelitian ini, dari segi akademis dapat memperluas ilmu pengetahuan tentang tanaman hortikultura dan dari segi praktiknya diharapkan dapat menjadi bahan acuan.

\section{METODE PENELITIAN}

\section{Waktu dan Tempat Penelitian}

Penelitian ini berlangsung selama 3 bulan dari bulan Desember 2019 sampai bulan Februari 2020 mulai dari persiapan sampai penyusunan laporan, dengan lokasi penelitian di Desa Palelon Kecamatan Modoinding Kabupaten Minahasa Selatan.

\section{Metode Pengumpulan Data}

Jenis data yang digunakan dalam penelitian ini adalah data primer dan sekunder. Data primer diperoleh melalui pengamatan langsung ke lapangan dan mengadakan wawancara langsung dengan petani menggunakan daftar pertanyaan (kuisioner). Data sekunder diperoleh dari instansi-instansi terkait dalam penelitian ini.

\section{Metode Pengambilan Sampel}

Pengambilan sampel secara purposive sampling yaitu secara sengaja, jumlah petani yang dijadikan sampel sebanyak 15 petani yaitu yang membudidayakan tanaman hortikultura (kentang, kubis, bawang).

\section{Konsep Pengukuran Variabel}

Biaya pengendalian hama dan penyakit yang dikeluarkan petani kentang, kubis, bawang dalam penggunaan pestisida selama satu kali tanam (Rp)?

\section{Metode Analisis Data}

Data yang digunakan dalam penelitian ini akan dianalisis secara deskriptif yang disajikan untuk mendeskripsikan atau menggambarkan data yang terkumpul dengan menggunakan tabel.

\section{HASIL DAN PEMBAHASAN}

\section{Deskripsi Daerah Penelitian}

Palelon adalah salah satu desa di Kecamatan Modoinding yang berada di Kabupaten Minahasa Selatan Provinsi Sulawesi Utara, yang terdiri dari 10 desa dengan luas wilayah 6.640 dan merupakan wilayah yang paling tinggi karena seluruh desanya berada di ketinggian $\pm 1100 \mathrm{~m}$ diatas permukaan laut. Jumlah penduduk yang ada di Desa Palelon 1495 jiwa, dengan jumlah 498 kepala keluarga. berikut:

Batas administratif Desa Palelon sebagai

a. Sebelah utara berbatasan dengan Desa Wulurmaatus

b. Sebelah barat berbatasan dengan Desa Insil

c. Sebelah selatan berbatasan dengan Desa Makaaroyen

d. Sebelah timur berbatasan dengan Lahan Pertanian 


\section{Karakteristik Responden}

\section{Umur}

Dalam Kamus Besar Bahasa Indonesia, masa kerja diartikan jangka waktu seseorang yang telah bekerja pada kantor, badan dan sebagainya. Masa kerja merupakan dimulainya waktu seseorang melakukan pekerjaanya sampai saat ini, sehingga kurun waktu tersebut dapat diartikan sebagai lamanya masa kerja seseorang. Untuk melihat umur responden dapat dilihat pada Tabel 1 .

Tabel 1. Umur Responden Petani Hortikultura

\begin{tabular}{cccc}
\hline NO & $\begin{array}{c}\text { Umur } \\
\text { (tahun) }\end{array}$ & $\begin{array}{c}\text { Jumlah } \\
\text { Responden }\end{array}$ & Persentase (\%) \\
\hline 1 & $<16$ & 0 & 0 \\
2 & $16-59$ & 14 & 93,3 \\
3 & $>60$ & 1 & 6,7 \\
\hline Jumlah & & 15 & 100 \\
\hline
\end{tabular}

Sumber : Diolah dari data primer, 2020

Tabel 1, umur responden petani hortikultura hampir semua responden masuk dikatergori usia produktif.

\section{Tingkat Pendidikan}

Tingkat pendidikan masyarakat dapat menjadi salah satu indikator kesejahteraan masyarakat. Untuk melihat tingkat pendidikan responden, dapat dilihat pada Tabel 2 .

Tabel 2. Tingkat Pendidikan Responden

\begin{tabular}{cccc}
\hline NO & $\begin{array}{c}\text { Tingkat } \\
\text { Pendidikan }\end{array}$ & $\begin{array}{c}\text { Jumlah } \\
\text { Responden } \\
\text { (petani) }\end{array}$ & $\begin{array}{c}\text { Persentase } \\
(\%)\end{array}$ \\
\hline 1 & SD & 5 & 33,3 \\
2 & SMP & 4 & 26,7 \\
3 & SMA & 6 & 40,0 \\
\hline Jumlah & & 15 & 100 \\
\hline
\end{tabular}

Sumber : Diolah dari data primer, 2020

Tabel 2, tingkat pendidikan responden tertinggi yaitu tingkat pendidikan SMA dengan persentase sebesar $40 \%$ dan terendah pada tingkat pendidikan SMP sebesar 26,7\%.

\section{Jumlah Tanggungan Responden}

Jumlah Tanggungan merupakan salah satu faktor masyarakat akan lebih bekerja untuk mendapatkan pendapatan cukup tinggi. Untuk dapat melihat jumlah tanggungan responden dapat dilihat pada Tabel 3 .
Tabel 3. Jumlah Tanggungan Responden

\begin{tabular}{cccc}
\hline No & $\begin{array}{c}\text { Jumlah } \\
\text { Tanggungan } \\
\text { (Orang) }\end{array}$ & $\begin{array}{c}\text { Jumlah } \\
\text { Responden } \\
\text { (orang) }\end{array}$ & Persentase (\%) \\
\hline 1 & 1 & 4 & 26,7 \\
2 & 2 & 8 & 53,3 \\
3 & 3 & 3 & 20 \\
\hline Jumlah & & $\mathbf{1 5}$ & $\mathbf{1 0 0}$ \\
\hline Sumber : Diolah dari data primer, 2020
\end{tabular}

Tabel 3, responden memiliki jumlah tanggungan tertinggi yaitu pada jumlah tanggungan 2 orang sebesar $53,3 \%$ dan terendah pada tanggungan 3 orang sebesar $20 \%$.

\section{Luas Lahan}

Luas Lahan pertanian merupakan faktor utama untuk berusahatani, luas lahan akan menentukan jumlah produksi pertanian khususnya tanaman hortikultura. Untuk melihat luas lahan responden dapat dilihat pada Tabel 4.

\begin{tabular}{cccccccc}
\multicolumn{1}{l}{ Tabel 4. Luas Lahan Responden } \\
\hline No & $\begin{array}{c}\text { Luas } \\
\text { Lahan }\end{array}$ & \multicolumn{3}{c}{ Jumlah Responden } & \multicolumn{3}{c}{ Persentase (\%) } \\
& Kentang & $\begin{array}{c}\text { Bawang } \\
\text { Daun }\end{array}$ & Kubis & Kentang & $\begin{array}{c}\text { Bawang } \\
\text { Daun }\end{array}$ & Kubis \\
\hline 1 & $<0,5$ & 9 & 14 & 12 & 60 & 93 & 80 \\
2 & $0,5-1$ & 4 & 1 & 3 & 27 & 7 & 20 \\
3 & $>1$ & 2 & 0 & 0 & 13 & 0 & 0 \\
\hline \multicolumn{2}{c}{ Jumlah } & $\mathbf{1 5}$ & $\mathbf{1 5}$ & $\mathbf{1 5}$ & 100 & 100 & 100 \\
\hline
\end{tabular}

Sumber : Diolah dari data primer, 2020

Dapat lihat pada Tabel 4, luas lahan yang digunakan untuk usahatani hortikultura terbanyak pada usahatani bawang daun pada luas lahan dibawah 0,5 ha sebesar $93 \%$, untuk diatas 1 ha terdapat pada usahatani kentang.

\section{Biaya Pengendalian Hama}

Pengendalian hama merupakan suatu kegiatan yang dapat mencegah atau mengatasi serangan hama terhadap tanaman, sehingga produksi tanaman tidak terganggu, akan tetapi pengendalian hama mengeluarkan biaya untuk petani, sehingga akan mempengaruhi pendapatan petani khususnya tanaman hortikultura. Untuk dapat melihat biaya pengendalian hama dapat dilihat pada Tabel 5.

\section{Tabel 5. Biaya Pengendalian Hama}

\begin{tabular}{lcc}
\hline \multicolumn{1}{c}{ Jenis Biaya } & Biaya/Ha & $\begin{array}{c}\text { Persentase } \\
(\mathbf{\%})\end{array}$ \\
\hline Penyiangan/ Pengolahan Lahan & $550.451,61$ & 24,05 \\
Pembibitan & $486.774,19$ & 21,26 \\
Pengendalian & $505.107,42$ & 22,06 \\
Pemeliharaan & $746.870,97$ & 32,63 \\
\hline Total & $\mathbf{2 . 2 8 9 . 2 0 4 , 1 9}$ & $\mathbf{1 0 0 , 0 0}$ \\
\hline Sumber : Diolah dari data primer, 2020 &
\end{tabular}


Berdasarkan Tabel 5, dapat dilihat bahwa biaya pengendalian hama tertinggi pada kegiatan pemeliharaan sebesar $32,62 \%$ dengan biaya $\mathrm{Rp}$ 746.870,97/ Ha. Sedangkan terendah pada kegiatan pembibitan sebesar $21,26 \%$ dengan biaya $\mathrm{Rp} 486.774,19 / \mathrm{Ha}$.

\section{Pengendalian Hama dan Penyakit Pada Tanaman Hortikultura}

Sejarah manusia kaya dengan peperangan melawan organisme penggangu tumbuhan. Lebih dari sepuluh ribu spesies insekta, gulma, nematode dan penyakit yang dapat menyerah tanaman yang dibudidayakan. Berbagai cara telah dikembangkan untuk mengubah keseimbangan kearah yang menguntungkan manusia. Salah satunya adalah pengendalian hama menggunakan bahan kimia yaitu pestisida. Pengendalian hama ini bisa dilakukan dengan melakukan penyemprotan zat kimia pada bagian tanaman atau tumbuhan. Olehnya itu pengendalian hama secara kimiawi sering dimasukkan kedalam langkah pemberantasan hama dan penyakit.

Dalam bidang pertanian pestisida merupakan sarana untuk membunuh hamahama pada tanaman. Dalam konsep PHT pestisida berperan sebagai salah satu komponen pengendalian. Cara penggunaan pestisida yang tepat merupakan salah satu faktor yang penting dalam menentukan keberhasilan pengendalian hama. Walaupun jenis obat manjur namun bila penggunaannya tidak benar maka menyebabkan sai-sianya penyemprotan. Hal-hal yang perlu diperhatikan dalam penggunaan pestisida diantaranya adalah keadaan angin, suhu udara, kelembapan dan curah hujan. Berikut cara petani melakukan pengendalian hama dan penyakit secara kimiawi pada tanaman hortikultura di Desa Palelon.

\section{Penyiangan/Pengolahan Lahan}

Penyiangan merupakan suatu kegiatan mencabut gulma yang berada diantara sela-sela tanaman dan sekaligus untuk menggemburkan tanah. Pengolahan tanah bertujuan untuk menciptakan kondisi fisik, kimia dan biologis tanah yang baik serta membunuh gulma atau tanaman yang tidak diinginkan misalnya rumput liar. Dalam penyiangan/pengolahan lahan pada tanaman kentang, bawang kubis di Desa Palelon, petani menggunakan jenis pestisida yaitu herbisida dan fungisida. Penyemprotan dilakukan dengan menggunakan Basmilang, Gramoxone, Roundup, Corono, Noxone, Kill Up. Sebelum melakukan penanaman maka dilakukan penyemprotan rumput pertama, kemudian dilakukan penyemprotan kedua yaitu 2 minggu sebelum tanam. Penyemprotan bertujuan untuk membunuh gulma atau tanaman yang tidak diinginkan misalnya rumput liar.

\section{Pembibitan}

Pembibitan tanaman adalah melakukan kegiatan menanam dengan suatu media tertentu untuk menghasilkan bibit baru. Mulai dari bentuk biji hingga munculnya tunas akar dan beberapa daun kecil sehingga bisa ditanam kembali. Petani menggunakan jenis pestisida yaitu herbisida, fungisida dan insektisida. Penyemprotan dilakukan dengan menggunakan Gibgro, Bigest, Decis, Sidamethrin, Manzate, Curacron, Bayfolan, Gardena D, Leili 2000, Mutiara Cair. Penyemprotan bertujuan untuk membunuh ulat, kutu daun, penyakit busuk daun dan penyakit busuk umbi. Serta mempercepat pertumbuhan pada bibit yang siap ditanam sehingga bibit atau benih tidak gampang busuk.

\section{Pengendalian}

Pengendalian berarti melindungi tanaman dari kerusakan yang ditimbulkan oleh makhluk-mahkluk atau organisme pengganggu yang disebut hama karena dianggap mengganggu kesehatan manusia, ekologi atau ekonomi. Untuk memaksimalkan hasil produksi, tanaman perlu dilindungi dari tanaman dan hewan pengganggu. Untuk melindungi tanaman dari serangan hama dan penyakit maka dilakukan penyemprotan dengan menggunakan herbisida, fungisida dan insektisida yaitu Manzate, Score, DI Grow, Antracol, Kuproxat, Extratin, Petrovita, Gandasil, Gandasil B, Bayfolan, Sidamethrin, Bio 8, Laconic. Penyemprotan dilakukan sebanyak $3 \mathrm{x}$ dalam satu musim tanam yang bertujuan untuk membunuh atau menghambat cendawan penyebab penyakit dan membunuh serangga perusak tanaman. 


\section{Pemeliharaan}

Pemeliharaan tanaman adalah merawat tanaman yang hidup dan membersihkan gulma atau tanaman pengganggu yang tumbuh disekeliling tanaman agar pertumbuhan tanaman berlangsung secara baik. Maka dilakukan penyemprotan dengan menggunakan herbisida, fungisida dan insektisida yaitu Curacron, Fastac, Decamon, Green Flora, Super Flora, Cypermex, Bayfolan, Antracol, Extratin, Petrovita, Manzate, Gandasil, Gandasil B, Bio 8, Sidamethrin. Penyemprotan dilakukan sebanyak $3 x$ dalam satu musim tanam yang bertujuan untuk membuat tanaman terhindar dari serangan hama dan penyakit yang menyebabkan busuk daun, busuk, batang, busuk buah.

\section{KESIMPULAN DAN SARAN}

Dapat $\begin{gathered}\text { Kesimpulan } \\ \text { disimpulkan bahwa biaya }\end{gathered}$
pengendalian tertinggi yang dikeluarkan petani
biaya pemeliharaan,
yaitu lahan, kemudian
penyiangan/pengolahan
pengendalian dan pembibitan.
Saran
Untuk petani disarankan agar
menggunakan jenis pestisida yang ramah
lingkungan agar mutu dan kualitas hasil
hortikultura terjaga untuk hasil produksi dan
konsumsi masyarakat.

\section{DAFTAR PUSTAKA}

Cahyono, B. (2001). Kubis Bunga dan Broccoli. Kanisius, Yogyakarta. Halaman 12-14.

Gunarto, Anton. 2003. Prospek Agribisnis Kentang G4 Sertifikat di Kabupaten Sukabumi.

Notohadinegoro, T., Johara. 2005. Faktor Tanah dalam Pengembangan Hortikultura. UGM press, Yogyakarta.

Pracaya. 2001. Kol alias Kubis. Penebar Swadaya. Jakarta

Prof. Dr. H. Zulkarnain, 2014. Dasar-Dasar Hortikultura. Penerbit PT Bumi Aksara Jakarta
Raharjaputra, H.S. 2009. Manajemen Keuangan dan Akuntansi. Jakarta. Salemba Empat. Samadi, B. 1997. Usaha Tani Kentang. Kanisius, Yogyakarta.

Sugiarti, S. 2003. Usaha Tani dan Pemasaran Cabai Merah. Yogyakarta: Jurnal Akta Agrosia. Soekartawi. 2002. Analisis Usahatani. UI Press. Jakarta. 